\title{
Benefit of Bed Raising to Manage Acid Sulphate Soil Under Industrial Forest Plantations Area
}

\author{
Ali Martinus $^{1 *}$, Dwi Setyawan ${ }^{2}$, Yuanita Windusari ${ }^{3}$ \\ ${ }^{1}$ Master Student at the Environmental Management, Universitas Sriwijaya, South Sumatra, Indonesia \\ ${ }^{2}$ Lecturer at Soil Science Study Program, Faculty of Agriculture, Universitas Sriwijaya, South Sumatra, Indonesia \\ ${ }^{3}$ Lecturer at the Environmental Management Study Program, Universitas Sriwijaya, South Sumatra, Indonesia. \\ *Corresponding author: mfamartin@gmail.com
}

Article history

\begin{tabular}{llll} 
Received & Received from reviced & Accepted & Available online \\
25 March 2019 & 01 April 2019 & 13 April 2019 & 13 April 2019 \\
\hline
\end{tabular}

\begin{abstract}
Industrial Forest Plantations (IFP) are intended to increase the productivity non-productive natural forest production. In South Sumatra Province IFP is widely developed in wetlands; one of them is in acid sulphate soils which have major problems with flooding and waterlogging. To solve this problem, the technology other than making drainage canals is Bed Raising. Bed Raising is to make beds to facilitate the implementation of planting, maintenance and harvesting, in addition to maintaining good soil aeration conditions. However, Bed Raising on acid sulphate soil raises a new problem is pirite oxidation, which affects the chemical properties of acidic sulphate soil. The purpose of this study was to see the benefits of bed raising in the management of acid sulphate land in IFP areas. This study uses survey methods and data are presented in tabulations. The results of this study indicate that the benefits of bed raising in the management of acid sulphate land are no longer flooded or waterlogging. While the results of chemical analysis of soil in bed raising plots are very acidic soil $\mathrm{pH}(\mathrm{pH}<3)$, Al-dd saturation is very high $(>70 \%)$, and high pyrite concentration $(>2.4 \%)$. This value is not suitable for plant growth.

Keywords: Flooded, Bed raising, acid sulphate soil
\end{abstract}

Abtrak (Indonesian): Hutan Tanaman Industri (HTI) dimaksudkan untuk meningkatkan produktivitas hutan produksi alam yang tidak produktif lagi. Di Provinsi Sumatera Selatan HTI banyak dikembangkan di lahan basah; salah satunya adalah pada tanah sulfat masam yang memiliki masalah utama banjir dan genangan. Untuk mengatasi permasalahan tersebut maka teknologi selain pembuatan saluran drainase adalah Bed Raising. Bed Raising yaitu membuat bedengan untuk memudahkan pelaksanaan penanaman, pemeliharaan dan panen, selain itu juga untuk menjaga kondisi aerasi tanah tetap baik. Namun Bed Raising pada tanah sulfat masam ini menimbulkan permasalahan baru yaitu terpaparnya lapisan pirit ke permukaan, yang berpengaruh pada sifat kimia tanah sulfat masam. Tujuan dari penelitian ini adalah untuk melihat manfaat dari bed raising dalam pengelolaan lahan sulfat masam pada areal HTI. Penelitian ini menggunakan metode survai dan data disajikan dalam tabulasi. Hasil penelitian ini menunjukkan bahwa manfaat dari bed raising pada pengelolaan lahan sulfat masam tidak lagi mengalami kebanjiran atau genangan. Sedangkan hasil analisa kimia tanah pada petak bed raising yaitu $\mathrm{pH}$ tanah sangat masam $(\mathrm{pH}<3$ ), kejenuhan $\mathrm{Al}$-dd sangat tinggi $(>70 \%)$, dan konsentrasi pirit tinggi $(>2,4 \%)$. Nilai ini tidak sesuai bagi pertumbuhan tanaman.

Kata kunci : Banjir, bed raising, lahan sulfat masam

\section{Introduction}

Forest Plantations in general have an increasingly important role, especially to meet timber needs, along with declining timber production from natural forests since the late $1980 \mathrm{~s}^{[1]}$. According to current estimates, the global area of plantations (including semi-natural forests) has increased from 167 million hectares to 280 million hectares from 1990 to 2015, with more than 100 million hectares of productive plantations and 54 million hectares of industrial plantations growing fast [2].

Plantations in particular are regulated and regulated in Government Regulation No.7 of 1990 concerning Industrial Plantation Forests Concession Rights. This type of forest is intended to increase the productivity of natural production forests that have been damaged or are no longer productive. Industrial Forest Plantation (IFP) ) is a production forest area whose management applies an intensive forestry cultivation system to supply and fulfill the availability of raw materials for the forestry industry, both in the form of wood or non-wood ${ }^{[3] .}$

The area of plantations in Indonesia has only reached 5,042,400 hectares, so various efforts are still needed to increase the realization of plantation development in Indonesia, including in South Sumatra Province ${ }^{[4]}$. The area of production forest in South Sumatra is around 1.7 million ha, and there are several companies holding permits for PFTFPU-IFP which develop forestry species on these wetlands ${ }^{[5]}$. 
Wetlands have specific characteristics related to the condition of inundated land, so that species can be developed in this area is certain types that can adapt to anaerobic conditions ${ }^{[6]}$. There are two types of wetlands developed for industrial plantations in South Sumatra, namely peat and acid sulphate fields. Both types of land have a major problem, is with flooding and waterlogging.

To solve the problem of flooding and waterlogging, especially during the rainy season, the technology or management actions taken in the land other than the construction of drainage channels is to apply the Bed Raising method. Bed Raising is meant to make beds to facilitate the implementation of planting, maintenance and harvesting, in addition to maintaining the condition of soil aeration to remain good, between bed raising, drainage canals are usually made ${ }^{[7] \text {. }}$

It turns out that the application of raising material on acid sulphate soils raises new problems, namely the exposure of surface pyrite layers, this occurs due to the elevation of soil material from drainage channels containing pyrite, which is placed on top of the soil layer. This pyrite layer is anaerobic or safe if it is reduced (waterlogged or below ground level), but it will be very dangerous for plants if they are in aerobic or oxidized conditions, because it will drastically reduce the soil $\mathrm{pH}$ (soil $\mathrm{pH}$ below 3 ) If the soil $\mathrm{pH}$ is low not only is the plant growth disturbed, but the plant will die. The oxidation of pyrite compounds produces sulfuric acid and jarosite minerals with a level of acidity that can disrupt plant growth ${ }^{[8]}$. In addition, a large amount of plant nutrients is also washed away from the soil. This study aims to see the benefits of bed raising in the management of acid sulphate land in IFP area.

\section{Material and Methods}

This research was carried out in the area of Industrial Forest Plantations (IFP) in South Sumatra Province. The execution time is from January to March 2019. The materials and tools used for this study are: Basic map of the research location, soil sample, aquadest, $\mathrm{H}_{2} \mathrm{O}_{2}$ solution. belgie drill, measuring tape, GPS, drop pipette, cup, $\mathrm{pH}$ meter, plastic sample and rubber.

This study uses a detailed survey method, with a scale of 1: 10,000 with a grid system per $200 \mathrm{~m}$, survey conducted on plots that have been carried out bed raising. For an area of 10 hectares, you will get 6 drill points or observation points (Figure 1). At each drill point, drilling is done using a belgie drill, $120 \mathrm{~cm}$ deep. Then each layer of soil profile taken by the drill will be observed and determined the physical properties of the field and test the pyrite content. For a complete analysis of soil samples composite soil was used from 6 observation points in the treatment plot. The soil sample taken will be analyzed for $\mathrm{pH}$, saturation of Al$\mathrm{dd}$, pyrite concentration in the laboratory.

The data obtained is processed by a tabulation system obtained from observations and data obtained from analysis in the laboratory.

\section{Sampling Path Sample Point on The Research Plot}

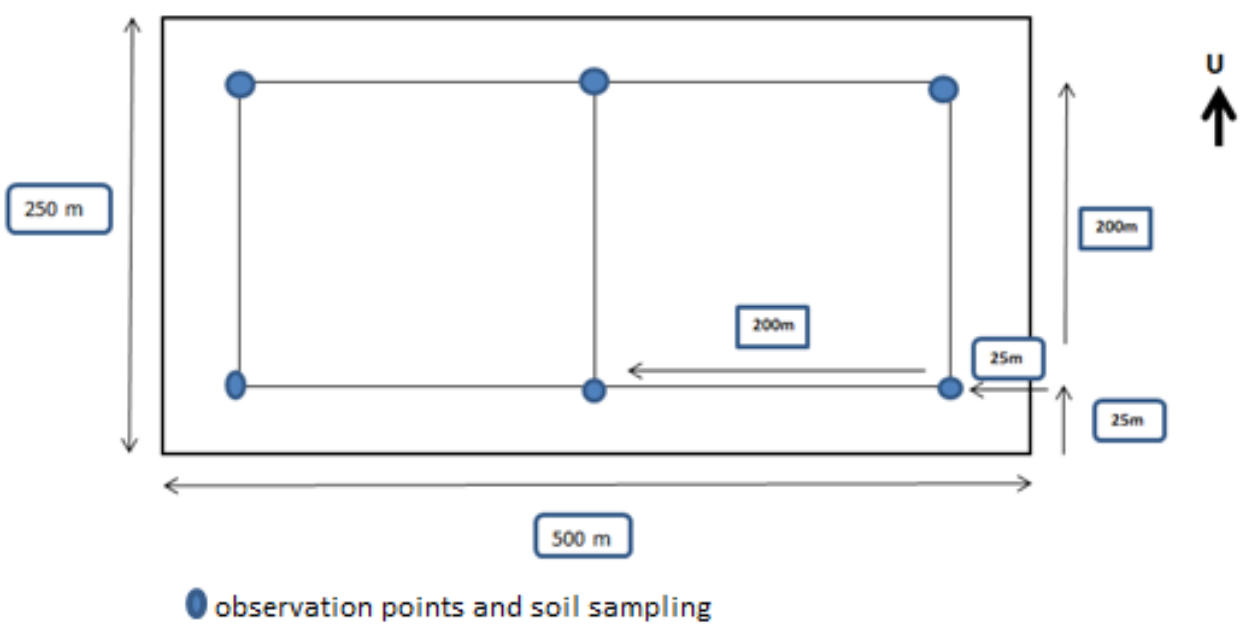

Figure 1. Design of sampling plots in plots

\section{Results and Discussion}

\subsection{Results}

From the results of analysis in laboratory samples on bed raising plots it has a very acidic soil $\mathrm{pH}$, with a soil $\mathrm{pH}$ range of 2.69-2.74 (Table 1). For Highest value of Al-dd saturation is at layer $1(0-30 \mathrm{~cm})$ with a value of $70.33 \%$. Value of the pyrite concentration in the bed raising plot has a high value in the range of 2.43$2.92 \%$. Physically, it is found that pyrite has been oxidized on the ground surface (Figure 2). For water table conditions at the bed raising location at the time 
of observation that is $80 \mathrm{~cm}$, while the water lavel

condition is $30 \mathrm{~cm}$ (Figure 3).

Table 1. Results of Soil Chemical Analysis at Bed Raising Location Sample Analysis Results

\begin{tabular}{lccc}
\hline Sample & & \multicolumn{2}{c}{ Analysis Results } \\
Deep $(\mathrm{cm})$ & $\mathrm{pH}$ & Al Saturation $(\%)$ & Pyrite Concentration $(\%)$ \\
\hline $0-30$ & $2,74(\mathrm{va})$ & $70,33(\mathrm{vh})$ & $2,43(\mathrm{~h})$ \\
$30-60$ & $3,01(\mathrm{va})$ & $2,56(\mathrm{vl})$ & $2,59(\mathrm{~h})$ \\
$60-100$ & $2,69(\mathrm{va})$ & $14,09(\mathrm{l})$ & $2,92(\mathrm{~h})$ \\
\hline
\end{tabular}

Soil Laboratory in IFP.

Information. : very acidic (va), very high (vh), high (h), very low (vl), low (l).

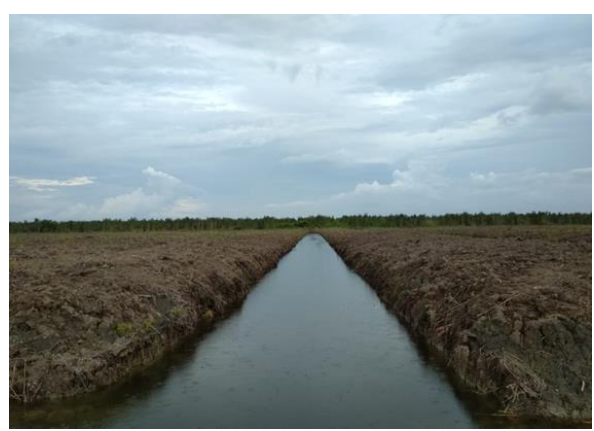

(a)

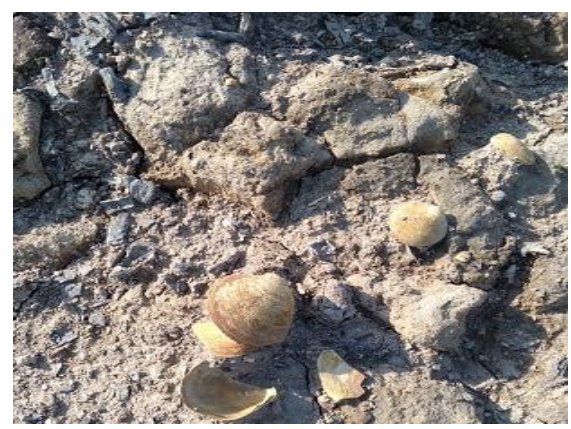

(b)

Figure 2. Physical condition (a) study location (b) example of pyrite

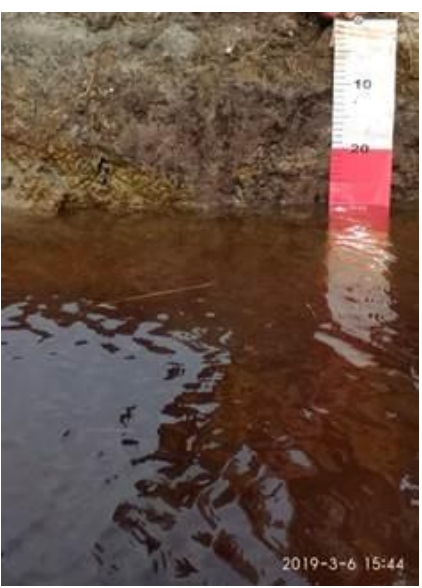

(a)

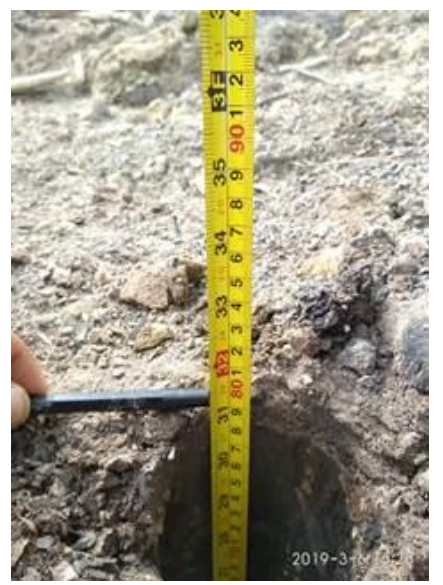

(b)

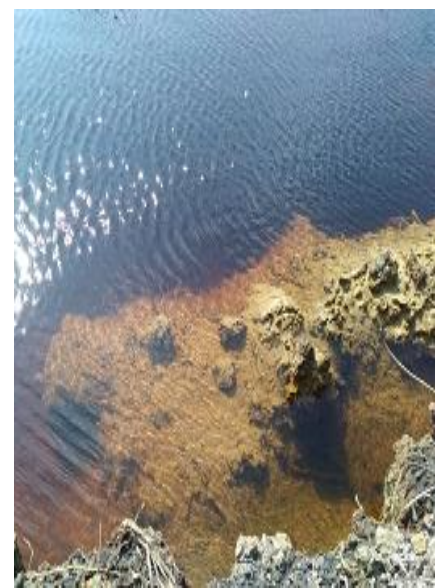

(c)

Figure 3. Water depth conditions: (a) water level, (b) water table, (c) canal conditions

\subsection{Discussion}

From the results of measurements in the field, the condition of the land did not experience waterlogging or flooding despite the rain or the tide conditions, this was also supported by the water table measurement data, was $80 \mathrm{~cm}$ and the water level data was $30 \mathrm{~cm}$.

From the data from observations and analyzes in this laboratory on soil chemical properties, it can be seen the chemical properties of soil in acid sulphate fields with the bed raising activities, especially some chemical properties that are harmful to plant growth.

From the results of measurements and analysis of soil $\mathrm{pH}$, it was found that the soil $\mathrm{pH}$ of the three soil layers was very acidic with a $\mathrm{pH}$ range of $2.69-3{ }^{[9]}$. The cause of this very acidic $\mathrm{pH}$ is because sulfidic or pyrite $\left(\mathrm{FeS}_{2}\right)$ material when exposed to air will form $\mathrm{H}_{2} \mathrm{SO}_{4}$ which can acidify the soil environment, so that the soil cannot be used for crop cultivation ${ }^{[10]}$, very acidic soil $\mathrm{pH}$ condition at the location of this research because of pyrite oxidation on the land due to the making of bed raising and canal excavation. Due to a decrease in groundwater, the pyrite at the top is open in an aerobic environment, and pyrite undergoes oxidation, the reaction of pyrite with Oxygen, which causes the release of a large amount of sulfate ions and hydrogen, so that the soil $\mathrm{pH}$ becomes very sour ${ }^{[11]}$.

Soil $\mathrm{pH}$ greatly determines plant growth and production. If the soil $\mathrm{pH}$ is lower than 4.0 in general there will be an increase in $\mathrm{Al}^{3+}$ in soil solutions which will have an impact on physically damaging the root system of plants, especially young roots, so that plant growth becomes obstructed ${ }^{[12]}$.

From the results of the Al-dd analysis it was found that the saturation level of Al-dd at layer $1(0-$ 
$30 \mathrm{~cm})$ was very high, while the second layer (30$60 \mathrm{~cm})$ and the third layer $(60-100 \mathrm{~cm})$ had a low to very low range. The high level of saturation of Al-dd in the coating (layer 1) is due to the low soil $\mathrm{pH}$ (very acidic) which triggers an increase in $\mathrm{Al}^{3+}$ in the soil solution ${ }^{[12]}$. On acid sulphate soils the process of soil soaking, because of the presence of pyrite compounds in the soil layer, which if oxidized due to being lifted to the surface or drought will result in the release of clay mineral gratings and produce $\mathrm{Al}^{3+}$ ions which are highly toxic to plants ${ }^{[13]}$.

Due to the high level of saturation of Al-dd at the location of this study, it can cause plant growth to be hampered, because nutrients, especially P elements that play a role in plant growth will be fixed and cannot be available to plants. The most nutrient problem that occurs in acid sulphate fields is the low level of $\mathrm{P}$ nutrient availability and high $\mathrm{P}$ fixation by $\mathrm{Al}$. $\mathrm{P}$ nutrients are one of the nutrients needed by plants. This nutrient functions for root growth, energy transfer in photosynthesis and respiration, fruit and seed development, stem strength and disease resistance ${ }^{[10]}$.

High $\mathrm{Al}$ content will cause poisoning for plants, including disruption of photosynthesis, development of chloroplast and biosynthesis of proteins, high $\mathrm{Al}$ will also interfere with the process of composing enzymes such as cytochrome, catalase and feroxidase ${ }^{[14]}$.

From soil chemical analysis, the results of all soil layers in this bed raising activity, both layers 1,2 and 3 , have high concentrations of pyrite ranging from $2.43-2.92 \%$. This is caused by pyrite oxidation due to bed raising activities that lift the soil layer material containing pyrite to the surface, and also supported by the decrease / distance of the groundwater due to elevation in the bed raising plot (water table value $80 \mathrm{~cm}$ at observation), so that when water the ground decreases, the pyrite layer will oxidize automatically. These pyrite compounds will be stable and harmless in anaerobic or inundated conditions. However, if the surface of the subsurface (groundwater) decreases to exceed the depth of the pyrite layer itself can cause the pyrite to oxidize and the soil becomes very acidic, this condition occurs because the reclamation carried out is not quite right ${ }^{[15]}$.

The high concentration of pyrite is clearly not very supportive for plant growth, because when the concentration of pyrite is high on the soil, it will affect the decrease in soil $\mathrm{pH}$ and help increase the saturation of Al-dd. Pyrite concentrations $>1.03 \%$ include the N1 class (Conditionally Suitable) for the Acacia mangium plant ${ }^{[16]}$.

\section{Conclusion}

The conclusions from the results of this study indicate that the benefits of bed raising in the management of acid sulphate land are no longer flooding and waterlogging. While the results of chemical analysis of soil in bed raising plots are very acidic soil $\mathrm{pH}(\mathrm{pH}<3)$, Al-dd saturation is very high (> $70 \%$ ), and high pyrite concentration (> 2.4\%). This value is not suitable for plant growth.

\section{References}

[1] Warman RD. 2014. Global wood production from natural forests has peaked. Biodiversity and Conservation 23.

[2] Pirard, R., H.Petit, H.Baral, R.Achdiawan. 2016. Impact of Industrial Plantation in Indonesia Analysis of Perception of Rural Communities in Sumatra, Java and Kalimantan. Center for International Forestry Research (CIFOR). Bogor.

[3] Republic of Indonesia Government Regulation No.7. 1990. Industrial Plantation Forest Concession Rights. www.hukumonline.com.

[4] Central Bureau of Statistics. (2014). South Sumatra in numbers: land area by type of land in South Sumatra Province 2011-2013. Palembang: Central Statistics Agency of the Province of South Sumatra.

[5] Central Bureau of Statistics. (2017). South Sumatra in numbers: Area of Production Forest. Palembang: Central Statistics Agency of the Province of South Sumatra

[6] Siahaan, H., A. Sumadi. 2016. Table of Standing of Wetland Industrial Plantation in Ogan Komering Ilir Regency, South Sumatra. Muhammadiyah University. Palembang.

[7] Kurnia, U., H. Suganda, D. Erfandi and H. Kusnadi. 2004. Soil Conservation Technology in Upland Vegetable Cultivation. Soil Research Center. Bogor.

[8] Noor, M. 2004. Swamp Land, Nature and Problematic Land Management Acid Sulfate. Raja Grafindo Persada. Jakarta.

[9] Soil Research Institute. (1983). Assessment Criteria for Chemical Properties of Soil. http://syekhfanismd.lecture.ub.ac.id/files/2013.

[10]Nasution, A.H., Fauzi, L.Musa. (2014). PAvailable Study in Potential Sour Sulfate Rice Fields. Online Journal of Agroecotechnology. ISSN No. 2337-6597. Vol.2, No.3: 1244- 1251, June 2014

[11] Susanti., P.D. 2012. What and what about acid sulphate soils? Environmental and Forestry Research and Development Center. Banjarbaru.

[12] Bopung, A. 2014. Effect of Water PH on Plant Growth.

https://infobopung.wordpress.com/2014/05/19/p owers-ph-air-to-growth-property.

[13] Widjaja-Adhi, I.P.G., Nugroho, D. Ardi, U.S. Karama. 1992. Tidal and swamp and coastal land resources: potential, limitations and utilization. Hal: 19-23. In: Partohardjono, S., M. Syam (eds). Minutes of the National Meeting on the Development of Agriculture for Tidal and Swamp Lands in Cisarua March 3-4, Bogor. 
[14] Sulistiyani., D.P., Napoleon, and A.G.Putra. 2014. Assessment of Soil Quality on Tidal Swamp Land for Corn Plants (Zea mays L) in Banyu Urip Village, Tanjung Lago District, Banyuasin Regency. Proceedings of the 2014 Suboptimal Land Seminar, Palembang, 26-27 September 2014. ISBN: 979-587-529-9.

[15] Annisa, W., and B.H. Purwanto. 2010. P Retention by Iron Oxides in Sour Sulphate Land After Land Reclamation. Journal of Land Resources Vol. 4 No. 1, July 2010.1

[16] Faculty of Agriculture. 2017. Soil Survey and Mapping of Marine Clay Derived Acid Sulfate Soils Palembang Region 2017. Bogor Agriculture University. Bogor. 